\title{
Situating Local Literacies at the Core of ELT Curriculum in Higher Education ${ }^{1}$
}

Las Literacidades Locales Situadas al Centro del Currículo de Inglés en la Educación Superior

\section{Yuly Andrea Nieto-Gómez and Amparo Clavijo-Olarte*2}

Universidad Distrital Francisco José de Caldas, Colombia

${ }^{1}$ Received: February 21st 2020/ Accepted: September 10th 2020

2 yulyandreanieto@gmail.com; aclavijo@udistrital.edu.co 


\section{Abstract}

This qualitative interpretive study carried out with four EFL teachers in an English for Academic Purposes (EAP) course at a private university in Bogotá, Colombia addresses the disconnect that exists between curricular content and the life of students in education. From our understanding of literacy as a sociocultural practice, we proposed a pedagogical approach that immersed teachers and students in community explorations to study local issues informed by different disciplines. Therefore, this study describes the ways teachers designed and implemented curriculum using community assets (Kretzmann \& McKnight, 2003) to develop student agency. The issues addressed by students in their inquiries included improving civic practices in the cycling route; fostering river preservation; environmental issues with garbage in Bogotá; and possibilities to access higher education for young populations in Colombia. Using a grounded theory approach, we collected and analyzed data from class discussions, curricular units, semi-structured interviews and class observation. Findings reveal that community explorations fostered students' agency towards studying social issues and promoted the construction of context-embedded opportunities for learning using students' realities and topics of local relevance (Canagarajah, 2005). The target language was used to reflect, pose problems, produce texts and participate in social reflections within an academic environment.

Key words: Foreign languages; literacy education; communities; teachers' role; higher education.

\section{Resumen}

Este estudio cualitativo interpretativo realizado con cuatro maestros de EFL en un curso de inglés para propósitos académicos en una universidad privada en Bogotá, Colombia, aborda la desconexión que existe entre el contenido curricular y la vida de los estudiantes. Desde nuestra comprensión de la literacidad como una práctica sociocultural, propusimos una pedagogía que involucró a maestros y estudiantes en exploraciones comunitarias para estudiar temas locales informados por diferentes disciplinas. Por lo tanto, este estudio describe las formas en que los maestros diseñaron e implementaron el plan de estudios utilizando los activos de la comunidad (Kretzmann \&McKnight, 2003) para desarrollar la participación estudiantil. Los problemas abordados por los estudiantes en sus indagaciones incluyeron la mejora de las prácticas cívicas en la ciclo ruta; preservación del río Tunjuelito; problemas ambientales con basura en Bogotá; y posibilidades de acceder a la educación superior para poblaciones jóvenes en Colombia. Utilizando un enfoque de teoría fundamentada, recolectamos y analizamos datos de discusiones en clase, unidades curriculares, entrevistas semiestructuradas y observación en clase. Los resultados revelan que las exploraciones de la comunidad fomentaron la participación de los estudiantes para estudiar los problemas sociales y promovieron la integración de las realidades del contexto para el aprendizaje utilizando temas de relevancia local para los estudiantes (Canagarajah 2005). El inglés se utilizó para reflexionar, plantear problemas, producir textos y participar en reflexiones sociales dentro de un entorno académico.

Palabras clave: Lenguas extranjeras; formación para la literacidad; comunidades; el rol de los docentes; educación superior. 


\section{Resumo}

Este estudo qualitativo interpretativo realizado com quatro professores de EFL em um curso de inglês para propósitos acadêmicos em uma universidade particular em Bogotá, Colômbia, trata sobre a desconexão que existe entre o conteúdo curricular e a vida dos estudantes. Desde a nossa compreensão da alfabetização como uma prática sociocultural, propomos uma pedagogia que envolveu a professores e estudantes em explorações comunitárias para estudar temas locais informados por diferentes disciplinas. Portanto, este estudo descreve as formas em que os professores desenharam e implementaram o plano de estudos utilizando os ativos da comunidade (Kretzmann \&McKnight, 2003) para desenvolver a participação estudantil. Os problemas tratados pelos estudantes nas suas indagações incluíram a melhora das práticas cívicas na ciclovia; preservação do rio Tunjuelito; problemas ambientais com lixo em Bogotá; e possibilidades de acessar a educação superior para populações jovens na Colômbia. Utilizando um enfoque de teoria fundamentada, coletamos e analisamos dados de discussões em aula, unidades curriculares, entrevistas semiestruturadas e observação em aula. Os resultados revelam que as explorações da comunidade fomentaram a participação dos estudantes para estudar os problemas sociais e promoveram a integração das realidades do contexto para a aprendizagem utilizando temas de relevância local para os estudantes (Canagarajah 2005). O inglês foi utilizado para refletir, propor problemas, produzir textos e participar em reflexões sociais dentro de um entorno acadêmico.

Palavras chave: Línguas estrangeiras; formação para a alfabetização; comunidades; o papel dos docentes; educação superior. 


\section{Introduction}

his qualitative interpretive study addresses the disconnect that exists between curricular content and the life and professional interests of students in English classes in higher education. It serves as a reflection on the exploration of local literacies in the teaching of English as a foreign language (EFL). While we widen our understanding of socially embedded pedagogies with teachers, we propose pedagogical and curricular connections with local resources to foster language and literacy development (Clavijo \& Ramírez, 2019).

This project emerged as a response to university EFL teachers' interest to participate in an innovative project that implied designing curricula, and creating local inquiries collaboratively with their students. They were accountable for teaching English as a requirement in the disciplines, but they were also interested in expanding the content to make students' community realities closer to their learning experience. Using community as curriculum was the starting point to engage students in innovative and contextualized practices in the classroom. The teachers were eager to learn about ways to establish links between teaching language and inquiring about social and environmental issues of the local context. Thus, we regarded community pedagogy as a possibility for teachers and students to recognize and critically address community problems using students' academic background to develop sensitivity towards their context.

Through field explorations and professional development workshops we invite teachers to recognize the sources available in the community to engage learners in knowledge embedded in social, cultural and material contexts (Gee, 2004). We believe that professional reflections and curriculum design that use local assets as resources to promote awareness of local literacies as content for learning were key aspects of the pedagogy we implemented with teachers in the language classroom.

The focus of this project is on community pedagogies (CP) that explore the local resources that influence the life of both teachers and students. Thus, students' funds of knowledge and experiences (Gonzales, Moll, \& Amanti, 2005) are critical resources to promote local inquiries among them. We considered community assets (Kretzmann and Mcknight, 1993) as powerful and valuable resources that involved learners and teachers in a critical reading of the community. One of the main goals of CP is to build learning environments that foster students' inquiries and engage them in text production using information from their professional fields and disciplines. Thus, the English language promoted reflection, problem posing, and student agency around social issues that they found locally relevant to inquire about. The question that guides our study explores How do EFL university teachers use local resources for curriculum and teaching? 


\section{Theoretical Framework}

We found the work of scholars and researchers whose effort has been recognized locally and globally key to understanding the relevance of local literacies in language and literacy education. We restate the contributions on critical issues on literacy (Freire and Macedo (1987); Luke and Woods (2009); and Comber (2013,2016); situated literacies (Gee, 2004); local literacies and community pedagogies, proposed by Sh \& Author 2 (2013) 2013; Sharkey, et al, (2016) and (Author2 \& R, 2019) critical views of local pedagogies by Canagarajah (2005); and place-based pedagogies by Greenwood (2013); and Demarest (2014). The former concepts allow to propose a communityoriented vision of language pedagogy and curriculum in ELT.

Through this theoretical support our stance is based on a sociocultural perspective to teacher education. It fosters teacher agency and a critical perspective to language and literacy, through involving the social and cultural contexts where individuals live. Thus, this literature review places agency as the engagement of actors with temporalrelational context in order to take action (Hempel-Jorgesen, 2015). It implies a central dimension in teachers' professionalism, since it involves developing the capacity to own social change and achieve educational social justice. One way to promote a contextualized practice is to focus teachers' pedagogy on students' social realities as the starting point of the development of literacy.

\section{Literacy as a Socially Constructed Practice}

When literacy is approached from a socially-situated perspective, the context becomes the starting point for teaching and learning as a process of interacting and negotiating with local texts. It shapes an individual's perception of their own reality. This occurs by teachers fostering a sense of agency in students, as they reorganize and transform their environment with the production of new texts. All uses of language are directly related to reality; therefore, literacy, as proposed by Freire \& Macedo (1987) refers to "how to write and rewrite reality, transforming it through a conscious work" (p. 23). Thus, literacy constitutes a framework to contextualize and raise awareness from the EFL classroom.

In this sense, literacy as a socially constructed practice, accounts for an exercise that evolves from the analysis and interrogation of the historical and cultural context of places (Comber, 2016). It problematizes social and classroom textual practices, through granting teachers and students the possibility to move from awareness to action (Pandya \& Ávila, 2013). Teachers and students can become researchers that use language to question and produce texts informed by their own reality. 
In this project, EFL teachers explore and learn with students about river preservation; city practices in the cycling route; environmental issues with garbage; access to public and private education to develop inquiry projects. This, according to Comber, Thomson, and Wells (2001) is a way to negotiate critical literacies, since these practices represent a teachers' commitment with ethical and pedagogical values that respect students' ways of knowing, as well as cultural and political histories. Thus, the local context in which teachers are immersed has a direct impact in curriculum, pedagogy, and theory. Now, situated literacies can be encouraged from pedagogies whose curriculum evolves from the negotiation with the place and the community. This leads us to base our research in CP, to use local literacies in the EFL curriculum.

\section{Local literacies and community pedagogies (CP)}

We believe that the practice of teaching and learning is concerned with collective and community actions that allow their members to make their own choices to deal with social processes, to exercise their citizenship. Accordingly, the local, as political, cultural, economic and identity reality, provides the individual with the basic instruments to construct a relationship with the global. For this reason, local knowledge becomes the essence of educational action by fostering cultural negotiation and dialogue (Mejía, 2011).

For Canagarajah (2005) "local knowledge has to be veritably reconstructedthrough an ongoing process of critical reinterpretation, counter discursive negotiation and imaginative application" (p. 12). This notion suggests that teachers are involved in the exploration of the relevance and complexity of local knowledge as to create a curriculum that integrates values, perceptions, and diversity within the community by fostering a continuous reflection that leads to a search for an alternate reality.

From this perspective, situated literacies present a way to evolve into critical literacy practices, which fosters a sense of possibility, agency, and transformation by recognizing the assets in the place and space of study (Comber, 2017). This idea is mirrored by Rincón and Clavijo (2016) whose community project with students from a low-socio economic public school in Bogotá fostered a community mapping experience, students crafting multimodal texts and creatively participating with others in a group blog while they critically reflected on their role within the community. Such local inquiry justifies that when teachers expose their students to challenging settings, based on a pedagogy of place, they envision the emancipatory role of language practices in their lives. This opposes the assumption that teacher, student, and school achievement can be measured by isolated, individualistic, and quantifiable classroom routines (Greenwood, 2013; Gruenewald, 2003a). 
Furthermore, when place along with cultural issues acts as the core of the curriculum, teachers and students can immerse themselves in the investigation of their society with a broader view by including different disciplines. Sharkey, Clavijo \& Ramírez (2016) conducted a study with teachers from different content areas in a public school that has sustained a partnership with the university for the last twenty years. The authors aimed at learning with teachers about how they developed and implemented CP, after designing curricular projects that connected students' lives and learning. Projects such as understanding the semiotics of graffiti, the analysis of the socioeconomic reality of the students' neighborhood, interviewing workers and families, and finding out about Colombian history from their own and their families' voices, display, as described by the participants, that appreciating local knowledge as a curriculum resource increases teachers' autonomy and ownership, as well as students' motivation, engagement, and family involvement.

\section{Community-oriented vision in a continual process of self- development}

Collaborating and learning with teachers in schools is a central goal for us as teacher educators in teacher education programs. By doing so, teachers and teacher educators can be immersed in a continual process of self-development through accepting and being aware of the sociocultural reality that influences classroom practices, while including both the linguistic and social needs of the learners (Kumaravadivelu, 2001). Accordingly, the language teacher becomes attentive to their practice as an opening not only to maximize learning opportunities in the classroom, but, at the same time to understand and transform them outside the classroom.

When developing sensitivity towards a situated curriculum, we acknowledge the recognition of learners' experiences that are negotiated in different places and times. The language teacher can get involved in an exploration of their roles as a community teacher (Murrell, 2011) who contextualizes the knowledge of the community, culture, and identity of the students and families they work with, in order to build a successful teaching practice in diverse settings. This standpoint questions the separation of the academic environment from the everyday world of students, since the interaction of situated learning and practice allows individuals to engage in a purposeful activity. Within this perspective, teachers build knowledge and analytical capacities by undertaking an analysis of the population they work with, learning about students, their families, incomes, and educational histories; exploring students' funds of knowledge; developing linguistic knowledge; revising what they know about pedagogy; and rethinking about literacies in this time and the new literacies teachers and students need to learn (Comber, 2001). 
Teachers' readiness to face socially-embedded pedagogies is based on dispositional as well as experiential factors that enable them to teach being aware and sensitive of their population. Mills and Ballantyne (2009) claim that two dispositional factors lead to commitment to social justice from the classroom: Self- awareness/ Self reflectiveness, which encompass thinking critically about one's own beliefs and attitudes towards the teaching practice. The authors posit that their pre-service teachers, first semester students as participants in their study, showed that such dispositions evolved developmentally by promoting intercultural experiences, support group experiences and educational experiences.

In terms of the experiential factors, teachers value field investigations that allow understanding the dynamics in a community, through the consideration of its physical spaces, individuals, local economy, institutions and associations (Kretzman \& McKnight, 1993). Such local recognition permits the teachers to critique official standardized models or imposed curricula which perpetuate overgeneralizing realities that do not fit in locally produced knowledge. On the contrary, standardized models may lead to the reinforcement of social inequalities (Gonzalez, 2007) restraining the teacher from being considered a valuable member of decision-making, teaching effectively, as well as becoming autonomous of their development.

\section{Methodology}

This qualitative interpretive study analyzes EFL teachers' praxis using CP in the context of higher education. The voices of the teachers are the most prominent as they become critical researchers of their own community, by using local resources as the foundations for their teaching practice.

\section{Context and participants}

This study took place at the language center in a private university in Bogota. The participants in the study are four EFL teachers who accepted the invitation to join the professional development workshops. They are from 28-35 years old. The participants were 3 female and one male teacher. They all hold a B.A. in foreign language teaching and have an overall experience with university students of more than 7 years. In this project they worked with students from Social communication, Industrial Engineering, Environmental Engineering, Marketing and Trade, systems engineering, psychology, Law, Economy, and digital marketing. 


\section{Data collection instruments}

We collected data through field notes of group discussions in the professional development sessions and class observations, curricular units of community projects, an initial and final semi-structured interview. Through discussions we could observe their perspective on literacy teaching, teachers' awareness of their students' world, and teachers being willing to transform their practice. The field notes intended to depict teachers' reflections about the ways they went about to identify and get out of deficit perspectives. The curricular units that teachers designed were a source of information and analysis of their decision making individually and in groups. Semi-structured interviews were also carried out to gain teachers' insights about constructing the curricular unit, identifying the links the teachers set with the local resources, the way in which they bring them to the curriculum and students' texts that reflect the local realities in their community. Finally, the field notes from class observations for three weeks provided insights about students' project development.

Grounded theory guided the framework of analysis, provided the systematic and yet flexible procedure to collect and analyze data that constructs understanding of the sources of information (Charmaz, 2006). The examination of data in this framework encompasses the process of sorting and synthesizing information through qualitative coding. This process consists of classifying segments that start to represent emerging themes and categories. It entails open coding, axial coding, selective coding and finally, using theories that support all the coding process, and permit theorizing as the final step in grounded theory. We utilized an analytical lens by examining the data sources (field notes, observations, curricular units and interviews) to identify teachers' pedagogical decisions and actions that integrated students' inquiries about different community issues in their teaching of English and their development of inquiry skills. Through the analysis of outcomes teachers rethinking pedagogy came out as a challenge in the process of teacher praxis.

\section{The pedagogical proposal}

The structure of the pedagogical project entailed participating in four professional development workshops that engaged teachers in readings about professional experiences of teacher researchers using community resources for language teaching; guided discussion about key concepts related to CBP; field experiences; curriculum design; implementation of community field projects with students; and reflections on the pedagogical outcomes.

The purpose of the workshops was to provide a space where teachers could reflect on their role, language literacy teaching, as well as the ways in which they can promote awareness on the local reality, by identifying the resources they can bring into the EFL curriculum, as to foster sensitivity on social issues from the academic culture. 
An example of teachers and students exploring local resources was the community mapping they conducted together by walking around the university to take pictures of the urban culture that called their attention. This exercise allowed them to pose problems about the local reality. Figure 1 describes the classification of resources that the teachers discovered.

Thus, the workshops were planned in a way that evolved from group discussion of professional readings, as well as conducting asset-mapping through the consideration of the physical spaces, individuals, local economy, institutions and associations (Kretzman \& McKnight, 1993) around the university. Each workshop lasted four hours, and the topics addressed were 1 ) How do we get out of deficit pedagogies; 2) what is the culture around the university; 3)How do we build a curricular unit) and; 4) what are the standards that guide our curricular unit and how to polish up curricular units.

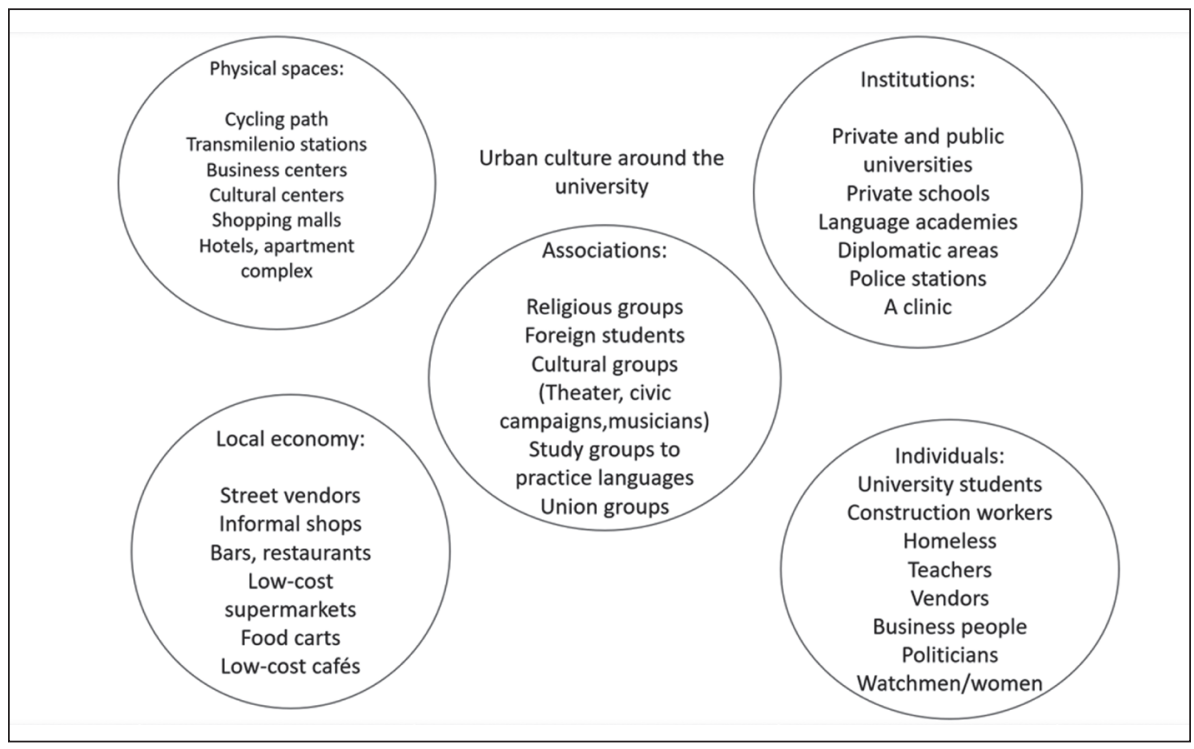

Figure 2. Steps to understand a context-embedded pedagogy

\section{Findings and discussion of findings}

The findings reveal two major themes in the praxis of EFL teachers using CP in higher education. Teachers rethinking the sources of curriculum to promote situated literacies and Situating local literacies within students' professional fields in ELT. 


\section{Teachers re-thinking the sources of curriculum to promote situated literacies}

For this study, rethinking the sources for curriculum implies taking professional risks towards understanding and acting together new pedagogies that require social exploration. The construction of context-embedded opportunities for learning using students' realities helped teachers question a static skill-based curriculum.

During Teacher Development (TPD) workshops all participants were adamant about considering their disposition, open-mindedness and creativity, as the starting point to renovate the curriculum with a community-oriented vision. Re-thinking the sources of curriculum inspired the exploration of community resources and members; with the aim of encouraging students to question, propose, and imagine the path to contribute to transformations from their disciplines of study. Teachers' disposition to rethink their pedagogical practice and curriculum using CP, led them to pose questions as to overcome recurrent challenges and tensions along the process. These included raising students' curiosity to learn English using community assets and developing students-led inquiries; designing a contextualized curricular plan that addresses inquiry topics from students' professional disciplines and the language goals for the English levels. Finally, teachers were interested in making inquiry projects the source to find a common ground through their fields of knowledge. Below, we provide an explanation on how teachers addressed CP in their practice. Figure 2 categorizes the process teachers underwent to understand a context-embedded pedagogy.

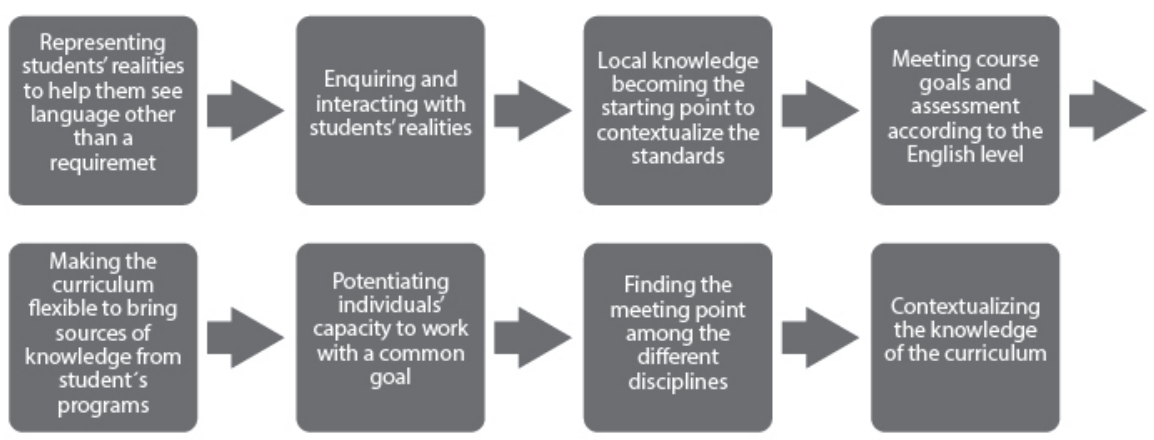

Figure 2. Steps to understand a context-embedded pedagogy

The steps portrayed in Figure 2 emerged from the professional reading discussions, and the construction of the curricular units. In the discussions during the initial workshops, teachers' first concern was regarding organizing content in the English 
curriculum. Teachers realized the need to interact with students' realities themselves to identify local assets and find the way to connect them to teaching and learning English. The statement below describes Teacher 4's reflection about what it takes to develop a project from being aware of students' world, by rethinking their pedagogical decisions.

The success of these kinds of pedagogical projects depends a lot on the teachers' knowledge of such context, students' interests, the situations and experiences lived every day. We need to leave the classroom as well, and be really curious about the reality that surrounds our students.

(Teacher 4. Semi-structured interview. December 6, 2018)

The social awareness about students' context leads teachers to become involved in the exploration of situated literacy development practices in the EFL class. Teachers read students' world and involved students in a multimodal text production that depicts their realities by providing out-of-class spaces to develop problem-posing skills. In-class teaching was oriented to gain new perspectives on the issues they identified. Teachers constantly mediated, scaffolded text production, and provided positive feedback.

In the following excerpt, teacher 3 refers to text production as a process that fosters social consciousness, sensitivity, and action taking. They reconsidered teaching writing beyond a skill development process to acquire the target language, and promoted text production as a form of cultural appropriation (Barton, Hamilton \& Ivanic, 2000).

I found [the experience] it very powerful and engaging for them and for me. I have always been concerned with the development of writing production, this curricular unit allowed the students to produce texts based on a social awareness, not only as a task, but following a process that permitted them to raise their own questions from their observations and concerns discovered in the mapping...the process taught students valuable lessons, such as that of working collaboratively with their classmates, community members, and academic experts, in order to gain sensitivity of what happens in the real world where they interact, and construct their writing skill from that consciousness.

(Teacher 3- interview. December 6, 2018)

The examples illustrate Freire and Macedo (1987; 1998) concept of literacy regarded as a medium that values the historical and existential experiences inside a cultural production, considered as an integral way for people to produce, reproduce, and transform meaning. Thus, teachers rethink sources of curriculum to promote situated literacies when they engage their students in an inquiry process that empowers them to become researchers of their own reality, promoting a curious spirit, and guiding 
them through the constructions of socially situated text. Hence, as Comber (2013) posits texts evolve from inquiring, analyzing and interrogating the context of places of study.

Teachers re-thinking the sources of curriculum to promote situated literacies is further explained through the second theme: situating local literacies within students' professional fields in ELT. It describes the ways teachers fostered the interaction of communities inside and outside the EFL classroom.

\section{Situating local literacies within students' professional fields in ELT}

In the study, the participating teachers situated local literacies through the observation of five key aspects suggested by Kretzmann and McKnight, (1993). They refer to associations, physical spaces, institutions, local economy, and individuals in the neighborhood. The starting point was to identify the assets that surround the context of the university and the community. In the projects developed by the teachers and students, the assets comprised institutions, neighborhoods, river preservation, cycling path, community members at/around university (academic community, family members, students, and street vendors).

Additionally, teachers reflected on students' professional programs as a local asset through which they geared curricular content, in order to develop awareness on social issues. The following response describes the teacher's perception on local resources.

For me a local resource is their own careers, when constructing the unit, I thought it was important to promote solutions from their different careers, in order for them to see possibilities to tackle the problem by using their academic knowledge. Finally, and what I consider innovative in my unit is that student's families, citizens, people in general, are not usually included as a source of information.

(Teacher 1 interview. November 1, 2018)

When students' professional disciplines became visible as a local resource, the teachers started to pose questions that brought about the synergies in the classroom. In the curricular units that addressed social problems, teachers situated local inquiries at the core and invited students to take actions collaboratively. Working in groups students provided peer feedback to gain perspectives from their field of expertise. The teachers promoted text production among students, to analyze the social issues from different perspectives; to consider peer feedback, and the fulfillment of language standards. 
For example, in the curricular unit from participant 3, the teacher proposed a project to create a pedagogical campaign about environmental issues with garbage in Bogotá. The students from the law school proposed possible solutions and supported their arguments in a written report using Colombian environmental regulations. Additionally, students designed together an interview to an expert professor on regulation to environmental issues. The teacher comments follow.

[...] I have always considered that students' programs need to be reflected on addressing solutions to the social issues they encounter. Then, the English class has to deal with content within students' fields. My strategy was to have students write driving questions for the analysis of environmental issues, because I think that is how they can give direction to the topics based on what they really want to enquire.

(Teacher 3. Interview December, 6, 2018).

From the teacher's quote we inferred that situated literacy is developed through granting students the possibility to move from awareness to action (Pandya \& Ávila, 2013) while becoming researchers that use language to question and produce texts informed and motivated by their own reality. In this case, students' practice is evolving from the analysis of issues which students find personally significant: their cultural context, academic interests, community problems, and aspirations to rename and reconstruct their own version of the world (Luke \& Woods, 2009).

Another relevant aspect for teachers to think about when guiding the community project, among the different disciplines, was the incorporation of class goals according to the CEFR. Sharkey and Clavijo (2012) assert that when working with a community asset-based perspective, teachers are invited to include the realities of the curriculum standards they must meet, and to place the local knowledge and resources as the starting point for their teaching. In addition to following English levels requirements (CEFR), the teachers planned their units in a way that permitted them to use valid forms of assessment for the EFL class. Through CP meeting the standards becomes a collaborative task of both teachers and students who involve the community as partners in the curriculum design (Demarest, 2014). Teachers integrated alternative forms of assessment from the process experienced by students in the inquiry project. Teacher 4 worked on a project that explored possibilities to access private and public higher education for the young population in Colombia. She created the assessment criteria with the students using the standards for the language level and including the experiences students had with their context exploration. The criteria to construct the text follows.

1. The social issue presented is clearly located and supported with evidences

2. The analysis from the different programs needs to be visible 
3. The text presents the bibliography

4. The text has gone through a revision process from other classmates (groups)

5. It is well structured, cohesive, and coherent.

6. The texts show task completion. (Class observation - Nov.12, 2018)

We can conclude that by exploring local literacies with students, the teachers widened their understanding of CP and curriculum design. Cochran-Smith (2005); Zeichner \& Conklin (2008) state that effective educators understand the surroundings of the population they work with, and therefore acknowledge their motivations. Teachers' effective praxis evidenced the relevance of studying social issues through inquiry projects led in the EFL classes.

Finally, the convergence of communities is evident in the curricular unit from students in teacher's 1 class. She proposed to make a historical record of what has happened to the Tunjuelito river. Thus, students collaboratively designed an interview to have more information about the river, asking elder people in their families who have always lived in Ciudad Bolivar, their neighbors, and the young population. Afterwards, the group visited the place. With this information in mind, the group conducted research about strategies for river preservation, how organizations can be distributed to clean these areas. In the interview, the teacher explained:

Finally, and what I consider innovative in my unit is that student's families, citizens, people in general, are not usually included as a source of information, I found that local resource as a key if we want students to be able to provide solutions that include all the members included in the problem or issue.

(Teacher 1. interview. November. 1, 2018)

In this fashion, the EFL class evolves into a cross disciplinary dialogue (Smith \& Sobel, 2010) which inspires teachers and students to explore problems and projects beyond their area of knowledge. To conclude, communities inside and outside the classroom intertwined when teachers guided their students to interact with people in communities as a learning opportunity to research social issues. Through this process, the teachers developed sensitivity towards a situated curriculum, and got involved in an exploration of their roles as community teachers (Murrell, 2011). 


\section{Conclusions}

From this research experience we inform the fields of literacy development and language teacher education. Our response to the question How do EFL university teachers use local assets as sources for curriculum and teaching? acknowledges teachers' use of local literacies for curriculum and teaching to promote language learning and community engagement. From this perspective, teachers re-thinking the sources for curriculum allowed them to enquire and interact with students' realities themselves to identify local assets and to find the way to connect their professional fields as local assets. It enabled them to be responsive to their students' interests and everyday sociocultural practices. Hence, teaching evolved from the problems that inquiry awoke in students, which emerged from the reality they feel committed and related to.

This study aimed at identifying the links that language teachers from a private university establish with local resources to make decisions about EFL literacy teaching. To accomplish this goal, the teachers were participants of teacher professional development (TPD) workshops based on the studies by Sharkey, et al (2016). Through this experience, they became involved in asset mapping in the university surroundings; they held group discussions about socially embedded pedagogies, and designed curricular units using students' realities as the core for their learning experience.

Through the intervention it was possible to observe how TPD invited teachers to reflect upon their pedagogical practice and curriculum. It was oriented to propose using local literacies for curriculum design and context-embedded pedagogies. It provoked tensions and challenges among the teachers; provided that they were constantly rethinking their pedagogical frameworks, in order to renovate their conceptions about the language class, literacy, the local reality, and decisions about curriculum design.

Additionally, the teachers managed to potentiate individual capacity by fostering the analysis of social issues from students' fields of knowledge. This way, students explored, interpreted, reflected upon their local reality though working collaboratively with a common goal, and contributing from what they know.

Furthermore, the teachers were able to intertwine communities from the EFL class by providing spaces for students to interact with the outside communities, and act informed by their reality. Their actions consolidated a community inside the English class to analyze and propose actions of betterment (McInerney, Smyth, and Down, 2011) from the academic environment.

Finally, this study is an invitation for language departments at universities, as well as for ELT university programs to consider teachers professional development beyond subject matter, linguistic content, and skill development. The language class needs to acknowledge and appreciate students' realities and local resources, so that they become 
the core of a contextualized curriculum that promotes students' inquiries and leads them to take actions informed by their own everyday practices. Teacher professional programs can challenge teachers to rethink their role and practices, by inviting them to enquire about their students' world, which allows to build a context-sensitive view of the act of teaching. 


\section{References}

Barton, D., Hamilton, M., \& Ivanic, R. (2000). Situated literacies: Reading and writing in Context. New York, NY: Routledge.

Canagarajah, S. (2005). Reclaiming the local in language policy and practice. Mahawh, NJ: Lawrence Elbaum Associates.

Charmaz, K. (2006). Constructing grounded theory: A practical guide through qualitative analysis. Sage publications.

Clavijo, A. (2014). Implementing community-based pedagogies in a language teacher education program in Colombia. Bogotá, Colombia: Universidad Distrital.

Clavijo, A., Guerrero, C., Torres, C., Ramírez, L., \& Torres, N. (2004). Teachers acting critically upon the curriculum: Innovations that transform teaching. Íkala: Revista de lenguaje y cultura, 9(15), 11-41.

Cochran-Smith, M. (2005). The new teacher education: For better or for worse? Educational Researcher, 34(7), 3-17.

Comber, B. (2013). Schools as meeting places: Critical and inclusive literacies in changing local environments. Language Arts, 90(5), 361-371.

Comber, B. (2016). Critical and inclusive literacies: Pedagogies of belonging. In B. Comber (Ed.), Literacy, place, and pedagogies of possibility (pp. 33-63). New York, NY: Routledge.

Comber, B. (2017). Literacy geography and pedagogy: Imagining translocal research alliances for educational justice. Literacy Research: Theory, Method, and Practice, 1-20. https://doi. org/10.1177/2381336917717479

Comber, B., Thomson, P., \& Wells, M. (2001). Critical literacy finds a” place”: Writing and social action in a low-income Australian grade 2/3 classroom. The Elementary School Journal, 101(4), 451-464.

Demarest, A. (2014). Place-based curriculum design. New York, NY: Taylor \& Francis.

Freire, P. (1998). Pedagogy of freedom: Ethics, democracy, and civic courage. USA: Rowman \& Littlefield.

Freire, P., \& Macedo, D. (1987). Literacy. Reading the word and the world. Massachusetts: Bergin and Garvey.

Gee, J. P. (2004). Situated language and learning: A critique of traditional schooling. New York: Routledge.

Gonzalez, A. (2007). Professional development of EFL teachers in Colombia: Between colonial and local practices. Íkala: Revista de Lenguaje y Cultura, 12(18), 309-332. 
Greenwood, D. (2013). A critical theory of place-conscious education. In J. Dillon \& M. Brody (Eds.), International handbook of research on environmental education (pp. 93-100). New York. Routledge. https://doi. org/10.4324/9780203813331.ch9

Gruenewald, D. A. (2003). Foundations of place: A multidisciplinary framework for place conscious education. American Educational Research Journal, 40(3), 619-654. https://doi. org/10.3102/00028312040003619

Kretzmann, J., \& McKnight, J. (1993). Building communities from the inside out: A path toward finding and mobilizing a community's assets. Evanston, IL: Institute for Policy Research.

Kumaravadivelu, B. (2001). Toward a postmethod pedagogy. San José, CA: San José State University

Luke, A., \& Woods, A. (2009). Critical literacies in schools: A primer. Voices from the Middle, 17(2) 9-18.

Mejía, M. R. (2011). Educaciones y pedagogías críticas desde el sur. Cartografía de la Educación popular. Lima: Editorial Quimantú.

Mills, C., \& Ballantyne, J. (2009). Pre-service teachers' dispositions towards diversity: Arguing for a developmental hierarchy of change. Teaching and Teacher education, 26(3), 447-454.

Moll, L. C., Amanti, C., Neff, D., \& Gonzalez, N. (2005). Funds of knowledge for teaching: Using a qualitative approach to connect homes and classrooms. Theory into practice, 31(2), 132-141.

Murrell, P. (2001). The community teacher: A new framework for effective urban teaching. New York, NY: Teachers' College Press.

Pandya, J., \& Ávila, J. (2013). Moving critical literacies forward: A new look at praxis across contexts. New York, NY: Routledge.

Sharkey, J. (2012). Community-based pedagogies and literacies in language teacher education: Promising beginnings, intriguing challenges. Íkala, 17(1), 9-13.

Sharkey, J., \& Clavijo-Olarte, A. (2012). Promoting the value of local knowledge in ESL EFL teacher education through community-based field assignments. In B. Medrado \& C. Reichmann (Eds.), Projetos e praticas na formação de professores de língua inglesa (pp. 39-58). Paraiba, Brasil: Editora Universitaria.

Sharkey, J., Clavijo, A., \& Ramírez, M. (2016). Developing a deeper understanding of community-based pedagogies with teachers: Learning with and from teachers in Colombia. Journal of Teacher Education, 67(3), 1-14. https://doi. org/10.1177/0022487116654005 
Smith, G., \& Sobel, D. (2010). Place-and community-based education in schools. Routledge. London: Routledge.

Zeichner, K. M., \& Conklin, H. G. (2008). Teacher education programs as sites for teacher preparation. In M. Cochran-Smith, S. Feiman-Nemser, D. J. McIntyre, \& K.E. Demers (Eds.), Handbook of research on teacher education: Enduring questions in changing contexts (pp. 269-289). New York: Routledge.

\section{Authors}

*Yuly Andrea Nieto-Gómez holds an MA in Applied Linguistics to TEFL from Universidad Distrital, Bogotá, Colombia. She is currently a professor of academic English at Universidad Nacional de Colombia. She is currently a member of the research group Lectoescrinautas. She has presented locally and internationally at conferences in language teaching education. Her latest publication is Promoting the Use of Local Literacies in EFL Pre-Service Teachers to Inspire their Teaching Practice" . In: Colombia Colombian Applied Linguistics Journal. Universidad Distrital Francisco José de Caldas

ORCID: https://orcid.org/0000-0002-3758-9213

Amparo Clavijo-Olarte holds a $\mathrm{PhD}$ in Education from The University of Arizona. She is currently a professor of Literacy and Qualitative Research Methods at Universidad Distrital Francisco José de Caldas in Bogota, Colombia. She is the director of the research group Lectoescrinautas LCPB (2000-2020). Has done international research collaborations with scholars from USA and U.K. and with public school teachers from five districts in Bogotá. Her research interest is related to Community based pedagogies and literacies in Language Teacher Education. Her most recent publications Pedagogias de la Comunidad a través de indagaciones locales en el contexto urbano de Bogotá (2019) and Developing a Deeper Understanding of Community-Based Pedagogies With Teachers: Learning With and From Teachers in Colombia (2016)

ORCID: https://orcid.org/0000-0002-3752-7020

How to reference this article: Nieto-Gómez, Y. A., \& Clavijo-Olarte, A. (2020). Situating Local Literacies at the core of ELT curriculum in higher education. GIST - Education and Learning Research Journal, 21, 27-46. https://doi.org/10.26817/16925777.830 